\title{
U-Pb Geochronology of two Devonian Large Igneous Provinces, Siberian Craton
}

\author{
SAMUEL DUCKWORTH-BATTYE ${ }^{1 *}$, SANDRA L. KAMO ${ }^{1}$, \\ RICHARD E. ERNST ${ }^{2}$
}

${ }^{1}$ University of Toronto, Toronto, Canada

(Corr: samuel.duckworthbattye@mail.utoronto.ca)

${ }^{2}$ Carleton University, Ottawa, Canada

Large Igneous Provinces (LIPs) have been considered as drivers of large scale climatic change ${ }^{[1]}$ and are associated with several ore deposit types, such as magmatic $\mathrm{Cu}-\mathrm{Ni}$-PGE deposits and kimberlites. This study applies high precision U$\mathrm{Pb}$ ID-TIMS (isotope dilution thermal ionization mass spectrometry) geochronology to intrusive rocks from the Yakutsk-Vilui and Altai-Sayan LIPs to improve our understanding of the timing and duration of large scale volcanism in Siberia during the Devonian. The Altai-Sayan LIP is located in the Central Asian Orogenic Belt in Siberia. ${ }^{[2]}$ It includes mafic to intermediate volcanic rocks as well as intermediate to felsic intrusive bodies. ${ }^{[2]}$ Timing of the AltaiSayan LIP is poorly constrained, with an approximate age of 408-393 Ma. ${ }^{[3]}$ The Yakutsk-Vilui LIP is located at the eastern edge of the Siberian craton and is represented by a rift system and radiating dyke swarm. ${ }^{[2]}$ It is associated with many diamondiferous kimberlites and is of some economic importance. ${ }^{[2]}$ Previous work has reported an age of 370-360 Ma. ${ }^{[4]}$ The Late Devonian Mass Extinction event represents one of the greatest declines in biodiversity in the Phanerozoic. Emplacement of the Yakutsk-Vilui (Y-V) traps has long been suspected of triggering some of the anoxic events that represent this extinction in the marine record. ${ }^{[5]}$ The Kellwasser anoxic event approximates the FrasnianFamennian (F/F) boundary (GSSP Coumiac quarry, France) within the late Devonian, and has been inconclusively linked to $\mathrm{Y}-\mathrm{V}$ magmatism. Our results from U-Pb CA-ID-TIMS dating methods on intrusive rocks of the Y-V LIP approximate the reported $\mathrm{F} / \mathrm{F}$ boundary age of $371.86 \pm$ $0.08 \mathrm{Ma}^{[6]}$

[1] Ernst, R.E., Youbi, N., (2017) Palaeogeogaphy, Palaeoclimatology, Palaeoecolology 478, 30-52. [2] Ernst, R.E., Rodygin S.A., Grinev O.M (2020) Global Planetary Change 185 [3] Kravchinsky, V.A., (2012) Global Planetary Change 86-87, 31-36. [4] Ricci, J. et al. (2013) Palaeogeogaphy, Palaeoclimatology, Palaeoecolology 386, 531-540. [5] Courtillot, V., et al. (2010). Earth and Planetary Science Letters, 300(3-4), 239-245. [6] Percival, L. M. E., et al. (2018). Scientific Reports, 8(1), 1-10. 